\title{
Hansen's disease: social representations of affected people
}

\author{
Hanseníase: representações sociais de pessoas acometidas
}

Lepra: representaciones sociales de personas afectadas

\author{
Raquel Santos Monte ${ }^{1}$, Maria Lúcia Duarte Pereira
}

Objective: to identify the social representations of leprosy among its carriers. Methods: qualitative study based on the Theory of Social Representations, conducted with 40 subjects with leprosy, divided into two groups (male and female). Data were collected through semi-structured interviews and free observation, submitted to thematic content analysis. Two categories were formulated. Results: it was found different aspects between men and women. Women highlighted issues related to the domestic sphere, care with family and body image; men signaled changes in routine and adaptation to the new condition. Conclusion: The health and especially the nursing model, must seek to understand the daily life of being a leprosy carrier, learning to deal with the differences in each individual, using educational activities that advance toward comprehensive care to the human being.

Descriptors: Leprosy; Integrality in Health; Nursing.

Objetivo: apreender as representações sociais sobre hanseníase entre seus portadores. Métodos: pesquisa qualitativa, fundamentada na Teoria das Representações Sociais. Realizada com 40 sujeitos com Hanseníase, divididos em dois grupos (masculino e feminino). Dados coletados por meio de entrevista semiestruturada e observação livre, submetidos à análise de conteúdo temática e formuladas duas categorias. Resultados: constataram-se aspectos diferenciados entre homens e mulheres. As mulheres destacaram questões relacionadas ao âmbito doméstico, cuidado com a família e imagem física; os homens sinalizaram mudanças na rotina e adaptação à nova condição. Conclusão: o modelo de saúde e, principalmente de enfermagem, deve buscar compreender o cotidiano do ser portador de hanseníase, aprendendo a lidar com as diferenças de cada indivíduo, utilizando ações educativas que avancem em direção ao cuidado integral ao ser humano.

Descritores: Hanseníase; Integralidade em Saúde; Enfermagem.

Objetivo: identificar las representaciones sociales de la lepra entre sus portadores. Métodos: estudio cualitativo basado en la Teoría de las Representaciones Sociales. Realizado con 40 sujetos con lepra, divididos en dos grupos (masculino y femenino). Datos recolectados a través de entrevista semiestructurada y observación libre sometidos a análisis de contenido temático y formuladas dos categorías. Resultados: se encontraron diferentes aspectos entre hombres y mujeres. Las mujeres destacaron los temas relacionados con la esfera doméstica, la atención con la imagen corporal y la familia; los hombres señalaron cambios en la rutina y adaptación a la nueva condición. Conclusión: el modelo de salud y, especialmente de enfermería, debe tratar de entender la vida cotidiana de la persona con lepra, aprender a lidiar con las diferencias de cada individuo, utilizándose de actividades educativas que permitan avanzar hacia la atención integral a las personas.

Descriptores: Lepra; Integralidad en Salud; Enfermería.

\footnotetext{
*Extracted from the dissertation "Hanseníase: representações sociais de pessoas acometidas sob a ótica de gênero", Universidade Estadual do Ceará, 2011.

${ }^{1}$ Universidade Estadual do Ceará. Fortaleza, CE, Brazil.
}

Corresponding author: Raquel Santos Monte

Rua Benjamim Brasil, 369, Jardim Cearense. CEP: 60.712-003. Fortaleza, CE, Brazil. E-mail: kelmonte@bol.com.br 


\section{Introduction}

Leprosy is one of the oldest and stigmatizing diseases that affect humans and is considered today a public health problem in many developing countries. In Brazil, there were more than 33,000 new cases in 2013, which places it as the second country with the largest number of leprosy carriers in the world ${ }^{(1)}$.

National data show that the disease has leaned toward stabilization of rates, but still at very high levels in the North, Midwest and Northeast regions. Ceara State is ranked as the tenth of the country in number of cases and the third in the Northeast region, with index of $25.34 / 100,000^{(2)}$.

With regard to Ceara, the reality does not differ from national situation. In 2013, the detection rate was of 23.6 new cases of leprosy per 100 thousand inhabitants, which is considered a very high index. In that state, 1,758 new cases of the disease in children under 15 years old have been reported from 2001 to 2013, with an annual average of 135 cases. The occurrence of the disease in this age group shows the existence of active transmission focus that requires control measures to break the chain of transmission. In this context, leprosy has still been as serious public health problem in the State ${ }^{(3)}$.

Leprosy is a curable disease in all its forms. The biggest problem is not in the biological, but in the social and cultural sphere. To this date, the impact caused by the disease affects the daily lives of people who have leprosy: constant threat of prejudice, suffering, abandonment, deformities and psychosocial problems.

Thus, it is believed that knowing the social representations about the disease and understanding the struggle of those who have it, considering the gender, will contribute to better adequacy of cases and the trajectory of health services, from the early diagnosis to the initial approach to the patient and family until the end of treatment.

Although the male-female opposition is very old in American and European mentalities, concepts related to gender are recent historical products. When it comes to health, women and men have significant differences, not only in terms of specific needs, but also regarding access to health protection. The disease can be a trigger of changes in family structure, placing the woman stricken with leprosy in double disadvantage due to discrimination based on gender and the fact of being sick.

Given the above, the question is: how do subjects with leprosy represent their illness? In order to answer this question, this research aimed to understand the social representations of leprosy to patients and their meanings.

\section{Method}

This is an exploratory and descriptive research with multi-method approach, based on the Theory of Social Representations. It is believed that the human being is a symbolic animal inside a social environment, with the ability to guide the representation that delimits the field of communications, culture, with their beliefs and values, guiding their conduct ${ }^{(4)}$. The Theory of Social Representations was adopted as theoretical framework of this study because it considers the possibility that represents how individuals and groups act in face of leprosy, allowing individual and collective understanding of the phenomenon.

The research was conducted in the city of Fortaleza, Brazil, in an ambulatory for people with leprosy of a State Reference Center for Dermatology from April to June 2011.

To develop the study, it was used as an inclusion criterion: being male or female, being older or equal to 18 years old and having started treatment for at least three months. Individuals with physical and/or emotional disorders that prevented communication were excluded. Following the criteria, 40 subjects, invited randomly, participated in the research. Interviews were closed by theoretical saturation. The total of participants were divided into two groups: 20 
women (FG) and 20 men (MG), aiming the application of the theory.

To product data, it was used the semi-structured interview and free observation techniques, and also a field diary. The interview was organized in two parts: the first, with socio-demographic data (gender, age, years of education, marital status, occupation, diagnostic time and operational classification of leprosy), and the second, with guiding questions related to the topic (describe what leprosy is for you and describe what being a man/woman carrier of leprosy is for you). The free observation technique was used to complement the analysis of the interviews.

Data relating to the socio-demographic profile were tabulated by using Excel version 8.0. Other data resulting from the interviews were submitted to content analysis ${ }^{(5)}$.

The interviews took place individually in medical offices available in the service before or after the scheduled consultations. They were recorded after participants' consent. They were collected by the researcher, as she had domain about the explored content. The time for each interview was on average 20 minutes.

Interviews were submitted to qualitative analysis technique and were organized in accordance with the following steps: pre-analysis, material exploration, treatment of results, inference and interpretation. This technique consists of explanation and systematization of the content of the messages and of expressions of this content $t^{(5)}$.

The corpus consisted of 40 interviews, and the paragraph was selected as context unit and the sentence as registration unit. Test results were discussed based on the theory of social representations and on the current literature on leprosy.

The study was approved by the Research Ethics Committee of Dermatology Reference Center Dona Libania, as protocol no. 001/2011.

\section{Results}

Of the 40 subjects, as shown in Table 1 , the majority of men $(17 ; 85.0 \%)$ and women $(13 ; 65.0 \%)$ were multibacillary type, with a higher proportion of people aged up to 40 years old, with up to eight years of education and lived with family income lower than three minimum wages, whose amount at the time the study was $\mathrm{R} \$ 510.00$, equivalent to two hundred five American dollars. As for marital status, there was a higher proportion of single men (11; 55.0\%).

Table 1 - Characteristics of the 40 people with leprosy, according to social, demographic and clinical variables

\begin{tabular}{|c|c|c|}
\hline \multirow{2}{*}{ Variables } & \multirow{2}{*}{$\begin{array}{c}\text { Female } \\
\mathbf{n}(\%)\end{array}$} & \multirow{2}{*}{$\begin{array}{c}\text { Male } \\
n(\%)\end{array}$} \\
\hline & & \\
\hline \multicolumn{3}{|l|}{ Age (years old) } \\
\hline$\leq 40$ & $11(55.0)$ & $10(50.0)$ \\
\hline$>40$ & $9(45.0)$ & $10(50.0)$ \\
\hline \multicolumn{3}{|l|}{ Schooling (years) } \\
\hline Illiterate & $2(10.0)$ & - \\
\hline $1-8$ & $12(60.0)$ & $12(60.0)$ \\
\hline$>8$ & $6(30.0)$ & $8(40.0)$ \\
\hline \multicolumn{3}{|l|}{ Marital status } \\
\hline Single & $8(40.0)$ & $11(55.0)$ \\
\hline Married & $9(45.0)$ & $9(45.0)$ \\
\hline Widow(er) & $3(15.0)$ & - \\
\hline \multicolumn{3}{|l|}{ Occupation } \\
\hline Do not work & $3(15.0)$ & $4(20.0)$ \\
\hline Work & $10(50.0)$ & $16(80.0)$ \\
\hline Housewife & $7(35.0)$ & - \\
\hline \multicolumn{3}{|c|}{ Family income (Minimum wage)* } \\
\hline$<3$ & $15(75.0)$ & $14(70.0)$ \\
\hline$\geq 3$ & $5(25.0)$ & $6(30.0)$ \\
\hline \multicolumn{3}{|c|}{ Operational classification } \\
\hline Paucibacillar & $7(35.0)$ & $3(15.0)$ \\
\hline Multibacillary & $13(65.0)$ & $17(85.0)$ \\
\hline
\end{tabular}


From the analysis of the interviews, five categories emerged, with their respective subcategories: Conceptions about leprosy (sociocultural knowledge, clinical symptoms, scientific and technical knowledge and aspects related to sex); Perceptions about the disease (self-perception and perception of others); Living with leprosy (change in routine and labor constraints); Aspects related to treatment (treatment compliance and search for spirituality); and Facing leprosy (acceptance of the disease and low self-esteem).

Of these, two categories were selected, which are considered relevant to the topic Conceptions about leprosy and Facing leprosy, since these categories are the one that best outlined the social representation of leprosy patients.

\section{Category 1: Conceptions about leprosy}

This category refers to the conceptions of subjects about leprosy and includes the knowledge and views of participants about the disease, assimilated through the socio-cultural interaction, experience of the symptoms of the disease, technical and scientific knowledge gained from other patients, health professionals or through the media and aspects related to sex.

It is subdivided into four subcategories: sociocultural knowledge, clinical symptoms, scientific and technical knowledge and aspects related to sex (Tabela 2).

Table 2 - Distribution of subcategories about leprosy, according to male and female groups

\begin{tabular}{lccc}
\hline \multirow{2}{*}{ Subcategories } & Male & Female & Total \\
\cline { 2 - 4 } & $\mathbf{n ( \% )}$ & $\mathbf{n ( \% )}$ & $\mathbf{n ( \% )}$ \\
\hline Sociocultural knowledge & $31(8.6)$ & $47(13.9)$ & $78(11.2)$ \\
Clinical symptomatology & $135(37.6)$ & $65(19.2)$ & $200(28.7)$ \\
$\begin{array}{l}\text { Technical and scientific } \\
\text { knowledge }\end{array}$ & $99(27.6)$ & $143(42.3)$ & $242(34.7)$ \\
Aspects related to sex & $94(26.2)$ & $83(24.6)$ & $177(25.4)$ \\
Total & $359(100.0)$ & $338(100.0)$ & $697(100.0)$ \\
\hline
\end{tabular}

When comparing the social representations between the two groups, it is clear that both had approximate understanding of the topic, which was revealed by the difference between the units of analysis of both groups: 359 , in males; and 338 in the women's group.

Participants had ideas about leprosy associated with knowledge from popular wisdom linked to sociocultural history of the disease and passages in the Bible. Both groups associated leprosy to the idea of isolation and horrible disease. Thinking that ... it does not have cure. First it was known only as leper. It did not have cure at first, because there were no medicines for these things (W13).

It was found, through the speeches, important relationship with history and myths referenced in the Bible. This, in turn, brought the issue of leper as a plurality of diseases, but for participants this was an aspect that was not clear and they continued to mention leprosy as a terrible disease. In fact, some people came to tell me that Hansen's disease was that old leper. The fingers would fell off. I do not know, I did not get to know the disease. But I also say this. So that's the reason I'm still afraid to talk because if it's really that disease it once was. It's a terrible thing (M18).

The female group referred to symptoms as disabling, the interpretation of the severity of the stains and wounds. Also, in one of the lines, the disease was understood as cancer. Leprosy for me is one of the worst diseases. Because what I understood when I was younger is that leprosy was as if it was cancer (W2).

In the speeches, it was clear that the pathological process was relevant in changing the routine of people with leprosy, being a disease that could not go unnoticed in the lives of their carriers. I'm feeling some very strange things, actually. Like fatigue, malaise and ... some things that we realize. I also had side effects, certain things, that we get ... even a little unmotivated (M4).

There are times when differences in social roles between a man and a woman contribute to the existence of different experiences in the sexuality of people with leprosy. In referring to physical activity in general, both sexes felt decrease in readiness, sometimes resulting in social isolation and other for 
fear of infecting people with whom they lived. It is a disease that I don't know from whom we get infected. It destroys people's lives. Because it is pain everywhere, it is joint pain, nerves pain. I cannot sleep right, there're stains everywhere. It's ugly, no one will even go to the beach (W3).

Statements showed that participants refer to the disease using terms they learned during contact with health professionals. Leprosy, according to doctors, if you take the medicine with a week or two, I do not know how long, it is no longer transmissible, so you can stay relaxed. But if people are not informed of this, they will be afraid of those people who are suffering because of leprosy (M2).

According to the emerged speeches, there are differing opinions regarding the aspects related to sex. For women, having leprosy has proved to be key differentiator about body image and care to the family, whereas men reported no difference in living with the disease. I think there's no difference, what is a woman? It's a person. What am I? I am a person. The woman is a human being, I am too. I find no difference, no (M15).

In one of the speeches in the women's group it was mentioned the lack of desire to have sex related to treatment. It's all different, as a woman I cannot go to certain places and people of my work are prejudiced. When it comes to sex, I do not feel like doing it anymore. I think it's because of the pills, I'm not the same woman, you know? The partner sometimes does not want to because he thinks he can be infected. It's very annoying (W3).

\section{Category 2: Facing leprosy}

This category presents thematic analysis units in which the subjects reported coping ways with the disease, even comparing to other diseases, such as AIDS, as well as through the declaration that they are not the only people with leprosy. So, some accepted the disease, others believed to be a life lesson, but in some cases, prejudice linked to the disease and changes in body image motivated low self-esteem. It is divided into two subcategories: disease acceptance and low self-esteem.
Table 3 - Distribution of subcategories on facing leprosy, according to male and female groups

\begin{tabular}{lccc}
\hline \multirow{2}{*}{ Subcategories } & Female & Male & Total \\
\cline { 2 - 4 } & $\mathbf{n ( \% )}$ & $\mathbf{n ( \% )}$ & $\mathbf{n ( \% )}$ \\
\hline Disease Acceptance & $187(67.0)$ & $111(91.0)$ & $334(74.3)$ \\
Low self-esteem & $92(33.0)$ & $11(9.0)$ & $103(25.7)$ \\
Total & $279(100.0)$ & $122(100.0)$ & $401(100.0)$ \\
\hline
\end{tabular}

By confronting the social representations of both groups, it was seen that the female group showed better coping with the disease, as they mentioned 279 units of analysis, whereas the male group reached 122 .

Individuals faced the disease through different attitudes, which are influenced by social factors in which they were inserted. Acceptance of the disease appeared in both groups, and was reported by many subjects, who even referred being glad to have the diagnosis of leprosy, since it is a curable disease compared to others that do not yet have cure, such as AIDS. It is better than having other types of disease. Better than having AIDS, something else. At least we know that it has cure. I am even happier because of that (W7).

Diagnosis, information and orientation cause emotional impact on the individual. My life is like this, regarding all things, it's okay, I have no problem with it. I'm sick, but to me it is normal, there are a lot of sick people. So it's not just me who is sick (M5).

The group of women highlighted, in the speeches, low self-esteem, represented by bodily changes and doubts about the possibility of cure. In the group of men, they sought inner strength and positive thinking as an aid in fighting the disease. We live our lives the way it presents itself. Tranquility, taking too much care. It 's like we live life with faith, without losing heart. Always having positive thinking (M18). Everyone has prejudice against us, it's annoying. In the others aspects of my life, it's all bad, I'm stressed about everything, I get angry with everything, I fight. I think that this disease will not come out of me at all. They say that I'll be healed 
within a year. But I don't know if I'll be healed. Then I get worried, I get nervous, then I have to take Diazepam to get better from my nerves (W14). I feel very nervous, and because I do not work, I keep the income of my family. I was too afraid for my children, because I do not want them to suffer what I am suffering (W1).

\section{Discussion}

In Brazil, until the 1970s, Hansen's disease was called leper, a term related to different injuries associated with divine punishment resulting from a serious sin and offense against God, which generated separation and even exclusion of patients by members of society. This exclusion caused that patients hide their condition and to this day the word leprosy (which is the same for leper, in Portuguese) carries the connotation that the individual has a medical condition that causes social impairment. Even today, the need to protect from social exclusion causes patients to move away from their common social activities and even relatives, with consequent damage to the proper treatment of cases ${ }^{(6)}$.

This disease also brings to mind the idea of ugliness. In a society that exalts beauty, especially for women, having the body spotted, as shown by the lines, is an additional suffering to be considered, because it excludes them or puts them out the standards of perfection demanded by society.

Considering the suffering resulting from illness, health education is an important space for the construction and transmitting of knowledge and practices related to the ways that each culture understands what a healthy living is, as an instance of production of subjects and social identities ${ }^{(7)}$.

Users can present multiple psychological reactions: denial, revolt, hiding or revealing their condition, up to acceptance through a process that varies for each person in time and intensity ${ }^{(8)}$.

Health education activities should be more effective, including for nurses facing directly this practice. It is necessary that such actions are based on concern for the other, favoring the care and not directing it, but respecting the existence of the human being. It is necessary to consider the different ways the experience of leprosy takes on people's lives and understand that health education activity is part of the same interface that connects the professional to the clientele ${ }^{(9)}$.

This result corroborates the survey conducted in Sao Paulo by stating that, didactically, we can infer that the proposed control activities for leprosy leave gaps, are too specific, not participatory or significant, making it difficult to reach the proposed actions ${ }^{(10)}$.

It is emphasized the importance of rescuing the clinical practice that not only decodes biopsychic issues, but also acknowledges life values, social conditions and ways of coping problems, adopting a practice that makes it possible to know, beyond the signs and biological symptoms of the subject, their experiences in daily life ${ }^{(8)}$.

Study on nursing consultation for leprosy patient in primary care in the state of Sao Paulo clarifies that the nurse should encourage the participation of clients in the care process by providing opportunities, stimulating the exchange of experience and discussion of problems and values implicit in their lives and their families, rather than taking prescriptive actions ${ }^{(8)}$.

This may contribute to prevention of disabilities, improving the quality of life of these individuals, as well as their families' lives. It is worth noting the need to intensify and strengthen the surveillance of leprosy, because it contributes to recommendations, promotion and analysis of the effectiveness of interventions, determining that the records of diagnosed cases and under treatment are continuously updated. It is essential to disclosing information acquired as a source of planning and evaluation of managers to be triggered ${ }^{(11)}$.

Study conducted in Guaiuba, CE, Brazil, aimed to identify the difficulties in compliance to the treatment for leprosy patients. It found, from the subjects' reports, that there is need to conduct 
a multidisciplinary approach toward the carrier of leprosy, aiming at improving information and guidance on disease and treatment. Therefore, the disease imposes, with its discovery, a myriad of changes, and the patient must be able to make the necessary adaptations. Professionals working in leprosy patients monitoring should be facilitators of these adaptations, seeking to promote health and patient's well-being ${ }^{(12)}$.

It is highlighted the importance of having a multidisciplinary team trained to fight the problem through systematic and individualized monitoring throughout the course of the disease, even in high ${ }^{(13)}$.

Among these approaches, one can cite the use of educational materials, in group activities conducted in health services, which helps to optimize the use of these resources in educational activities, increase knowledge about different diseases, and institute comprehensive health care practices. Therefore, reception studies of educational materials reveal themselves as valuable strategy for decentralization of communicative activities promoted by health programs. They also make possible the participation of different social groups on the steps of the communication process ${ }^{(14)}$.

Another issue that deserves attention on studies on leprosy, specifically on the stigma related to leprosy, is the relationship between healthy people and those who are in treatment or are cured. There is seeking for this question, this social situation, in the physical presence of each other, whether in an informal conversation or not. In this contact, when there is rejection, it is evident the removal of those less enlightened about the issue, about the disease. This removal, contrary to what most people think, still happens today. Few health professionals and other citizens know the situation of leprosy in Brazil ${ }^{(15)}$.

It is observed that the health system is intrinsically related to other aspects of culture, as well as a social system is not dissociated from the social organization of a group. Thus, the way how a particular social group thinks to maintain health and face episodes of illness it is not dissociated from the world view and overall experience that this has concerning other aspects and socio-cultural dimensions. Understanding how people viewed the health-disease-care process and interfered with selfesteem is important for the development of actions that contribute to the recovery of health and disease coping $^{(15)}$.

Often, the patient embodies the social stigma, struggling in the very acceptance and adaptation process, as he is faced with a new condition. The resolution of difficulties depends on internal resources and on social support provided mainly by family, professionals and the health service.

Thus, for the actions aimed at these individuals to be effective, they must be imbued with knowledge of the difficulties inherent to non-adherence to treatment they experience. For a holistic care, health services need to dissipate the prejudices and stigmas. Thus, this research confirms that nursing in primary care requires from nurses competence to make decisions, enabling interventions consistent with clients' needs, and it is essential to recognize that attention to the individual, the family and the community requires focused vision ever more for human care ${ }^{(12)}$.

\section{Final Considerations}

The social representations obtained in this study allowed the identification of symbols and metaphors about leprosy preserved from the early Christian era and maintained to the present day. The disease was represented for both men and women as an ugly disease that generates prejudice and discrimination. However, women pictured it more emphatically as an annoying and stressful disease, that makes one sees everything bad in life, that takes all over the inner person, and changes the body image, making them ugly, which keeps them indoors, not to be exposed to the sun and society, so that they cannot be judged. Therefore, they considered leprosy as something that 
destroys life. Men stressed the importance of having positive thinking as they needed to feel good to take care of family.

This research deserves attention for public policy actions in relation to leprosy, as they have yet to move forward especially regarding integration between the three levels of action, primary, secondary and tertiary. That way, the decentralization of the leprosy elimination program would be more efficient to ensure care to users in these three levels.

Thus, the care of people affected by leprosy can be introduced in a health system based on the comprehensive and humanized assistance to control the disease and may contribute to treatment adherence and break of transmission chain.

So, one of the ways of this research aimed at stimulating health education in context with the reality of the individual through their experience in face of the disease, considering them as women and men who need quality of care provided.

The nursing care model must seek to understand the daily life of being a carrier of leprosy, learning to deal with the difference, using transformative educational activities, aiming to advance towards the humanization of care.

\section{Collaborations}

Monte RS and Pereira MDL contributed to the project design and planning, analysis and interpretation of data, drafting and preparation of the article and final approval of the version to be published.

\section{Referências}

1. Organização Mundial de Saúde. OMS divulga situação mundial da hanseníase [Internet]. 2014 [citado 2014 Sept. 4]. Disponível em: http://www. paho.org/BRA/index.php.
2. Ministério da Saúde (BR). Portal da Saúde [Internet]. 2010 [citado $2014 \mathrm{dez}$ 9]. Disponível em:http://portal.saude.gov.br/portal/sau/ profissional/area.cfm?id_area=1466.

3. Secretaria da Saúde do Estado do Ceará. Campanha faz busca de casos de hanseníase em escolas [Internet]. 2014 [citado 2014 jul 31]. Disponível em: www.saude.ce.gov.br

4. Alexandre SG, Pereira MLD, Monte RS, Brasil EGM, Barbosa JSM, Moura SKB. Social representations of sexuality developed by women in the context of Aids. Rev Rene. 2013; 14(1):120-9.

5. Bardin L. Análise de conteúdo. São Paulo: Edições 70; 2011.

6. Silva MCD, Paz EPA. Educação em saúde no programa de controle da hanseníase: a vivência da equipe multiprofissional. Esc Ana Nery. 2010; 14(2):223-9.

7. Colomé JS, Oliveira DLLC. Educação em Saúde: por quem e para quem? A visão de estudantes de graduação em enfermagem. Texto Contexto Enferm. 2012; 21(1):177-84.

8. Silva MCD, Paz EPA. Educação em saúde no programa de controle da hanseníase: a vivência da equipe multiprofissional. Esc Anna Nery. 2010;4(2):223-9.

9. Duarte MTC, Ayres JA, Simonetti JP. Consulta de enfermagem: estratégia de cuidado ao portador de hanseníase em atenção primária. Texto Contexto Enferm. 2009; 18(1):100-7.

10. Instituto Lauro de Souza Lima. Fundação Paulista contra a Hanseníase. Secretaria da Saúde (SP). Coordenadoria de Serviços de Saúde. Instituto. Fundação Paulista contra a Hanseníase. Manual da Oficina de Educação e Ensino/Aprendizagem: ações educativas no controle da hanseníase. Bauru (SP): Instituto Lauro de Souza Lima, Fundação Paulista contra a Hanseníase; 2014.

11. Oliveira JCF, Leão AMM, Britto FVS. Análise do perfil epidemiológico da hanseníase em Maricá, Rio de Janeiro: uma contribuição da enfermagem. Rev Enferm UERJ. 2014; 22(6):815-21. 
12. Luna IT, Beserra EP, Alves MDS, Pinheiro PNC. Adesão ao tratamento da Hanseníase: dificuldades inerentes aos portadores. Rev Bras Enferm. 2010; 63(6):983-90.

13. Rodrigues FF, Calou CGP, Leandro TA, Antezana FJ, Pinheiro AKB, Silva VM, et al. Knowledge and practice of the nurse about leprosy: actions of control and elimination. Rev Bras Enferm. 2015; 68(2):297-304.
14. Santos AK, Ribeiro APG, Monteiro S. Hanseníase e práticas da comunicação: estudo de recepção de materiais educativos em um serviço de saúde no Rio de Janeiro. Interface. 2012; 16(40):205-18.

15. Martins PV, Caponi S. Hanseníase, exclusão e preconceito: histórias de vida de mulheres em Santa Catarina. Ciênc Saúde Coletiva. 2010; 15(supl.1):1047-54. 